\title{
INDUSTRIAL MAGNETRON SPUTTERING OF ZrN/Cu NANOSTRUCTURED COATINGS FOR ANTI-BACTERIAL PURPOSES
}

\author{
${ }^{1}$ Sahand BEHRANGI, ${ }^{2}$ Gabriela SUKOVÁ, ${ }^{1}$ Vilma BURŠíKOVÁ, ${ }^{1} P a v e l$ SOUČEK, \\ ${ }^{2}$ IVo SEDLÁČEK, ${ }^{3}$ Vjačeslav SOCHORA, ${ }^{1}$ Petr VAŠINA \\ ${ }^{1}$ Masaryk University, Faculty of Science, Department of Physical Electronics, Brno, Czech Republic, EU, \\ behrangi@mail.muni.cz \\ ${ }^{2}$ Masaryk University, Faculty of Science, Department of Experimental Biology, Czech Collection of \\ Microorganisms, Brno, Czech Republic,EU, gsukova@gmail.com \\ ${ }^{3}$ SHM, s.r.o, Šumperk, Czech Republic, EU, sochora@shm-cz.cz
}

https://doi.org/10.37904/nanocon.2021.4314

\begin{abstract}
In the present study, the anti-bacterial and mechanical properties of the $\mathrm{ZrN} / \mathrm{Cu}$ nanostructured coatings were studied. Copper was introduced as the anti-bacterial agent owing to its substantial activity against bacteria. Industrial reactive magnetron sputtering was utilized to synthesize the films with varying copper contents. Mechanical properties were measured using nanoindentation and discussed in relation to the chemical composition. The inhibitory efficiency of the films was tested against the two most common bacteria, including gram-negative (E. coli) and gram-positive (S. aureus) bacteria. We observed that the anti-bacterial efficiency of the samples significantly improved with increasing the copper amount. After 80 min exposure, the coatings with copper amount $>12$ at $\%$ showed $100 \%$ activity against both types of bacteria. The highest hardness measured was $28.5 \mathrm{GPa}$ for the low copper coating followed by a gradual decrease with increasing copper.
\end{abstract}

Keywords: Magnetron sputtering, bacteria, anti-bacterial efficiency, hardness, chemical composition

\section{INTRODUCTION}

Bacterial infection could cause tremendous problems in human societies. The bacteria-related issues have been recognized in many areas such as medical tools, food industry, health facilities and so forth. The bacterial adhesion to the surface, colonization and biofilm formation are ascribed for the consequent issues. Furthermore, most of the hazardous bacteria could survive on the surfaces for a long time. If such surfaces are touched, these adherent bacteria could transform to the human body and cause serious illnesses. Therefore, many efforts have been put into solving this problem. Amongst, production of some anti-bacterial films has been attracted much interest in the last years. The development of such a layer not only leads to the killing of bacteria on the surface but also improves the mechanical properties of the substrate as to slow down the degradation rate $[1,2]$.

Two well-known elements with impressive anti-bacterial activity are silver $(\mathrm{Ag})$ and copper $(\mathrm{Cu})$. Both mentioned metals are able to kill the bacteria in contact with them. Thus, production and characterization of the films containing either $\mathrm{Cu}$ [2-5] or $\mathrm{Ag}$ [6-10] have been studied in the recent years. However, Cu-containing films are preferable to $\mathrm{Ag}$ as $\mathrm{Cu}$ is an essential trace element and the human body could release it [11]. Copper can kill bacteria by releasing $\mathrm{Cu}$ ions which destroy their cell walls and cell membranes [4].

Zirconium nitride $(\mathrm{ZrN})$ is a well-known hard and wear-resistant material which have been studied by numerous researchers to synthesize coatings with improved mechanical properties. Therefore, by adding a third element one can obtain the tailored properties e.g. mechanical and anti-bacterial properties in the case of $\mathrm{Cu}$ addition [11]. Thanks to its high production rate and ability to produce films on the substrates with different geometries, 
reactive magnetron sputtering has become a promising method to produce such coatings like $\mathrm{ZrN} / \mathrm{Cu}$ which will be discussed in this paper.

$\mathrm{Cu}$ is immiscible in ZrN structure and crystallizes separately as the second phase to form the so-called nanocomposite. Nanocomposites are composed of at least two discrete phases which are mutually immiscible. One phase form fine dispersion within the other phase. It has been observed that nanocomposites can exhibit better mechanical, magnetic and electronical properties than the ordinary coatings [12-14].

The current work focuses on the $\mathrm{ZrN} / \mathrm{Cu}$ nanocomposite films synthesized by industrial magnetron sputtering to be used as anti-bacterial protective films. The films were prepared with different copper contents to observe the effect of copper concentration on the resultant properties. Chemical composition and mechanical properties of the films were measured. Furthermore, the killing efficiency of the films were measured against a gramnegative (Escherichia coli) bacterium and a gram-positive (Staphylococcus aureus) bacterium. The main privilege of our work is the much shorter exposure time compared to the literature. This ensures the killing of high number of bacteria colonies in a shorter time and having a cleaner surface.

\section{MATERIALS AND METHODS}

All the coatings were produced by SHM company utilizing the industrial sputtering machine. A hybrid method was applied as the combination of arc evaporation (for $\mathrm{Zr}$ target) and magnetron sputtering (for Cu target). The amount of copper altered through the varying magnetron power. The arc curent was $150 \mathrm{~A}$ and magnetron power varied from $0.5 \mathrm{~kW}$ to $3 \mathrm{~kW}$. All the coating parameters are presented in the Table 1.

Table 1 Process parameters for the synthesis of $\mathrm{ZrN} / \mathrm{Cu}$ films

\begin{tabular}{|c|c|c|c|c|c|c|}
\hline Sample & $\begin{array}{c}\text { Arc } \\
\text { current } \\
(\mathbf{A})\end{array}$ & $\begin{array}{c}\text { Magnetron } \\
\text { power } \\
(\mathbf{k W})\end{array}$ & $\begin{array}{c}\text { Deposition } \\
\text { time } \\
(\mathbf{m i n})\end{array}$ & $\begin{array}{c}\text { Deposition } \\
\text { temperature } \\
\left({ }^{\circ} \mathbf{C}\right)\end{array}$ & $\begin{array}{c}\mathbf{N}_{2} \text { pressure } \\
(\mathbf{P a})\end{array}$ & $\begin{array}{c}\text { Bias } \\
(\mathbf{V})\end{array}$ \\
\hline Cu0 & 150 & 0.5 & 60 & 400 & 1.5 & -50 \\
\hline Cu6 & 150 & 1 & 60 & 400 & 1.5 & -50 \\
\hline Cu12 & 150 & 1.3 & 60 & 400 & 1.5 & -50 \\
\hline Cu25 & 150 & 2.2 & 60 & 400 & 1.5 & -50 \\
\hline Cu29 & 150 & 3 & 60 & 400 & 1.5 & -50 \\
\hline
\end{tabular}

Polished Si (100) was used as substarte for the coatings. Prior to process, degreasing of samples was performed using ultrasonication of the Si substrates in the ethanol medium. Furthermore, before the depsotion, the samples underwent a sputter clening process to roughen their surface and to eliminate any surface scale or contamination. After the deposition process completed, the samples were cooled inside the chamber down to the ambient temperature.

Tescan Mira3 Scanning Electron Microscope (SEM) equipped with X-ray Energy Dispersive Spectroscopy (EDS) detector was employed to measure the elemental composition of the films. X-ray Diffractometry (XRD) was employed to characterize the phases of the microstructure. This was done utilizing Rigaku Smartlab Xray diffractometer using $\mathrm{Cu} \mathrm{Ka}$ radiation with a wavelength of $0.15418 \mathrm{~nm}$.

Hysitron TI950 Triboindenter equipped with a Berkovich tip was employed to measure the hardness and elastic modulus of the coatings.

For anti-bacterial testing, the common bacteria present normally on human skin either as contamination (Escherichia coli CCM3988) or as a commensal (Staphylococcus aureus CCM4516) were picked. The sampled bacteria were obtained from the Czech Collection of Microorganisms (CCM) in Brno, Czech Republic. From the original $24 \mathrm{~h}$ culture on trypton soya agar (TSA) at $37^{\circ} \mathrm{C}$, a $1^{\circ}$ McFarland suspension in saline 
solution was prepared. $1 \mathrm{ml}$ of this suspension was pipetted into $9 \mathrm{ml}$ of saline solution for creating a final inoculum with the concentration of $3 \times 10^{7} \mathrm{CFU} / \mathrm{ml}$ for $S$. aureus. For $E$. coli, the inoculum was diluted 1:10 twice into final inoculum (1:10 into primary inoculum and then 1:10 again into final inoculum) with the concentration of $3 \times 10^{6} \mathrm{CFU} / \mathrm{ml}$. These concentrations were chosen after optimization, where it was found that without twostep dilution of the $E$. coli suspension, the final plate counting was made impossible due to overcrowding of the plate with a high number of growing colonies. $10 \mathrm{ml}$ of final inoculum was then pipetted onto sterilised coated samples, covered with cover slip and incubated at room temperature and humidity for $80 \mathrm{~min}$. After incubation, the plates were put into $5 \mathrm{ml}$ of saline solution and shaken at $37^{\circ} \mathrm{C}$ for $10 \mathrm{~min}$. Following shaking, $100 \mathrm{ml}$ of the suspension was pipetted onto TSA plates in triplicates, spreaded with a spreader and incubated at $37^{\circ} \mathrm{C}$ for $24 \mathrm{~h}$. After $24 \mathrm{~h}$ the plates were taken out and colonies were counted.

Anti-bacterial efficiency $(E)$ of the films was calculated by dividing the number of killed colonies on the coatings over the number of survived colonies on the control samples according to the equation (1).

$E(\%)=\frac{\text { Number of killed bacteria after the exposure time }}{\text { Number of bacteria on the control sample after the exposure time }}=\frac{N_{C}-N_{S}}{N_{c}} \times 100$

where:
$N_{c}-$ number of the colonies survived on the control sample
$N_{s}-$ number of the colonies survived on the test sample

\section{RESULTS AND DISCUSSION}

The results of the EDS measurement are shown in Table 2. As can be seen in this table, the copper content is changing from $\sim 0$ at\% to $\sim 30$ at\% by varying magnetron power. Also, the amount of $\mathrm{Zr}$ and $\mathrm{N}$ are changing accordingly because nitrogen is only consumed by $\mathrm{Zr}$ while, $\mathrm{Cu}$ does not form any stable bond with nitrogen.

Table 2 Chemical composition of the ZrN/Cu coatings measured by EDS

\begin{tabular}{|c|c|c|c|}
\hline Sample & $\begin{array}{c}\mathbf{C u} \\
(\mathbf{a t} \%)\end{array}$ & $\begin{array}{c}\mathbf{Z r} \\
\text { (at\%) }\end{array}$ & $\begin{array}{c}\mathbf{N} \\
\text { (at\%) }\end{array}$ \\
\hline Cu0 & 0.7 & 50.79 & 48.51 \\
\hline Cu6 & 6.74 & 47.04 & 46.22 \\
\hline Cu12 & 12.82 & 43.20 & 43.98 \\
\hline Cu25 & 25.86 & 36.76 & 37.38 \\
\hline Cu29 & 29.84 & 34.85 & 35.32 \\
\hline
\end{tabular}

XRD was employed to have a better view of the microstructure of the coatings as well as to characterize the phases formed during sputtering process. The XRD spectra are demonstrated in Figure 1. The estimation of the grain size of the films are presented in Table 3. The XRD results are in consistence with the EDS results as only peak corresponding to $\mathrm{Cu}$ and $\mathrm{ZrN}$ are present. The two-phase nanocomposite films composed of $\mathrm{Cu}$

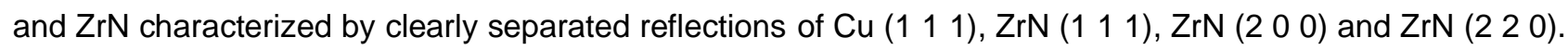
The formation of a separate copper grains is more distinguished with increasing copper content. At lower $\mathrm{Cu}$ amounts, the absence of $\mathrm{Cu}$ reflections implies that the $\mathrm{Cu}$ is either in an amorphous state or the size of $\mathrm{Cu}$ grains and their quantity is so small that their diffraction intensity is below the detection limit [13]. It can be seen that the $\mathrm{ZrN} / \mathrm{Cu}$ films have polycrystalline structures. The crystallinity of films slightly decreases with the incorporation of $\mathrm{Cu}$ as can be implied in Table 3. 
Hardness and elastic modulus of the films are plotted in Figure 2. As can be seen in this graph, mechanical properties of $\mathrm{ZrN} / \mathrm{Cu}$ films are strongly affected by Cu concentration. The hardness and elastic modulus both decrease with the copper content of the coatings. This is a consequent of the growing portion of the soft phase $(\mathrm{Cu})$ and its segregation as a separate phase in the microstructure. The hardness drops from $28.5 \mathrm{GPa}$ for $\mathrm{Cu} 0$ to $15.1 \mathrm{GPa}$ for Cu29. Likewise, the elastic modulus decreases from $336 \mathrm{GPa}$ for Cu0 to $242 \mathrm{GPa}$ for Cu29.

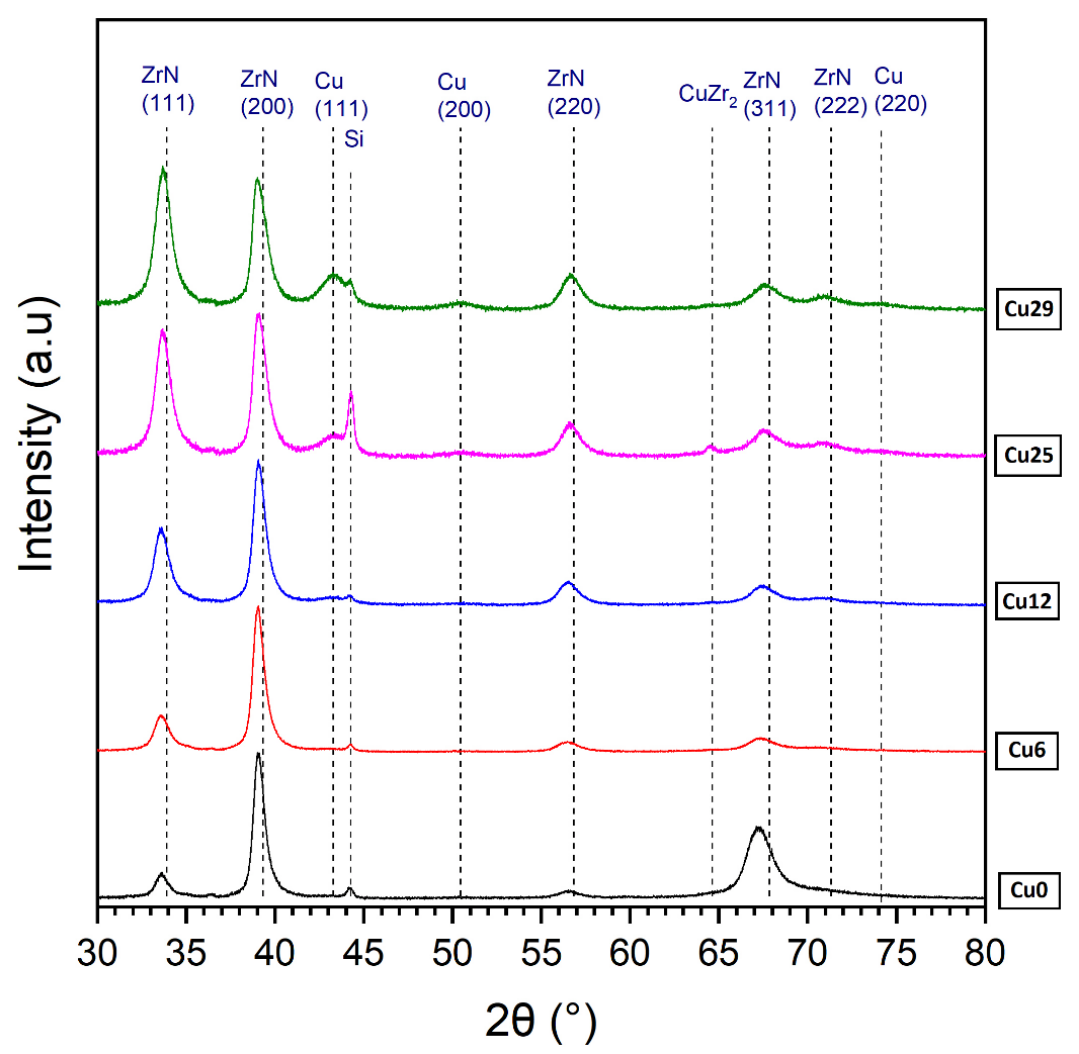

Figure 1 XRD spectra of the $\mathrm{ZrN} / \mathrm{Cu}$ coatings

Table 3 Grain size of the $\mathrm{ZrN}$ phase in the microstructure of the $\mathrm{ZrN} / \mathrm{Cu}$ coatings

\begin{tabular}{|c|c|c|c|c|c|}
\hline Sample & Cu0 & Cu6 & Cu12 & Cu25 & Cu29 \\
\hline Grain size (nm) & 8.40 & 7.76 & 7.82 & 7.69 & 7.49 \\
\hline
\end{tabular}

Anti-bacterial efficiency of the $\mathrm{ZrN} / \mathrm{Cu}$ coatings with different $\mathrm{Cu}$ concentrations against $\mathrm{E}$. coli and $\mathrm{S}$. aureus are plotted in Figure 3. The efficiency values are calculated using equation (1) after 80 min contact time of the surface with bacterial solution. From this figure, it is clear that the $E$ value of the films strongly depends on the concentration of $\mathrm{Cu}$. The killing efficiency of the $\mathrm{ZrN}$ films without any $\mathrm{Cu}$ is insignificantly low. However, addition of $\mathrm{Cu}$ even in low concentrations leads to the substantial improving of anti-bacterial efficiency. Consequently, the samples with $>12$ at $\%$ Cu show almost $100 \%$ killing efficiency against both bacteria. This indicates that for the excellent anti-bacterial efficiency, the $\mathrm{ZrN} / \mathrm{Cu}$ films must contain $>12$ at\% $\mathrm{Cu}$. In this research, the contact time of bacteria with the surface of the samples was significantly lower compared to the literature $[3,11,15]$. This was intentionally done to make the results closer to the real working conditions. For example, if these films are to be applied on some parts like door handles, the killing of the bacteria in shorter times results in having an almost bacteria-free surface after being touched by people. 


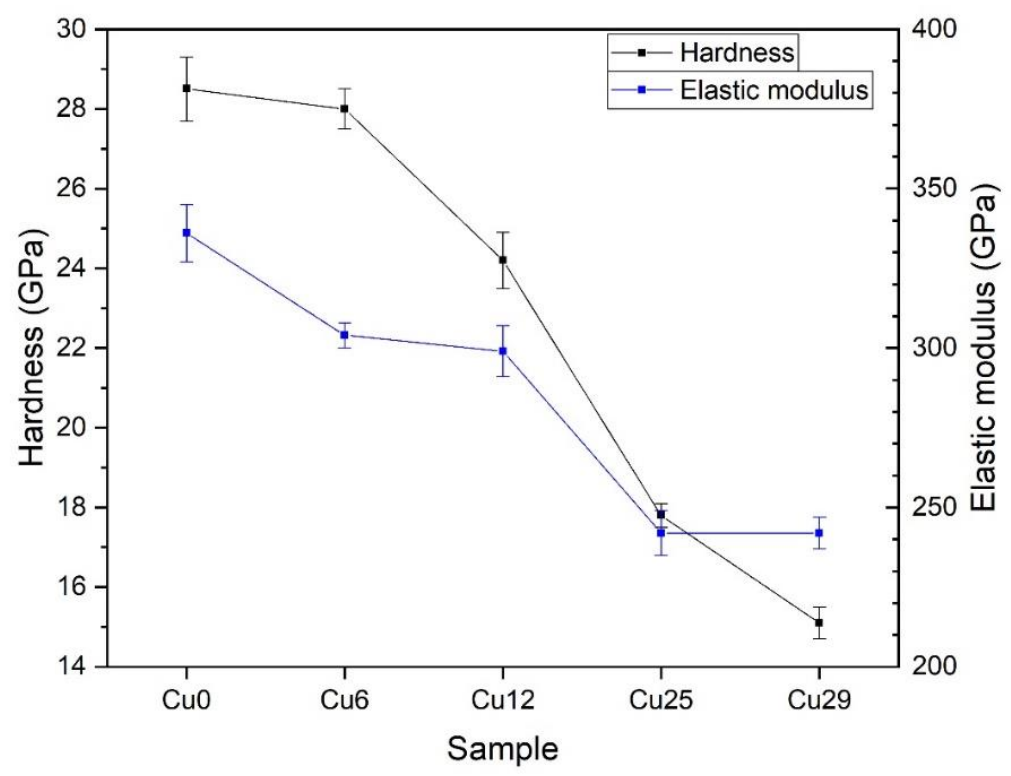

Figure 2 Hardness and elastic modulus of the $\mathrm{ZrN} / \mathrm{Cu}$ coatings.

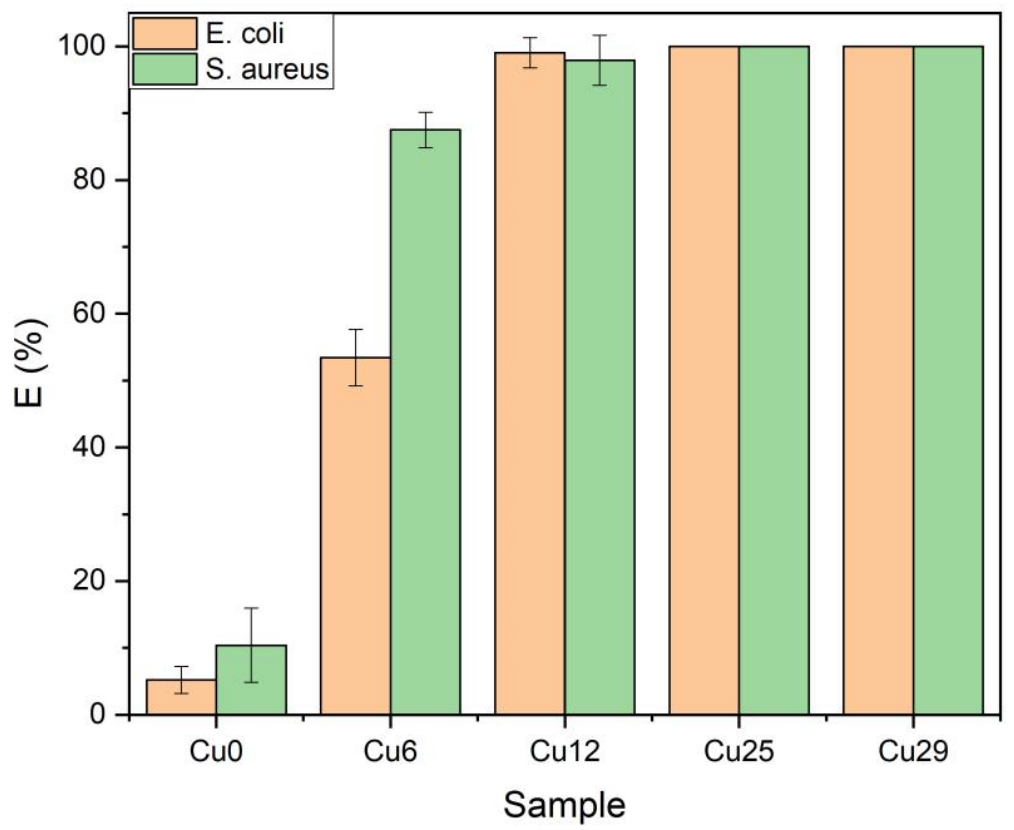

Figure 3 Anti-bacterial efficiency of the $\mathrm{ZrN} / \mathrm{Cu}$ coatings against two kinds of bacteria after $80 \mathrm{~min}$ exposure time

\section{CONCLUSIONS}

The Cu-containing ZrN films were synthesized utilizing reactive magnetron sputtering method. According to the XRD measurements, $\mathrm{ZrN}$ and $\mathrm{Cu}$ phases were formed separately in the microstructure leading to the formation of nanocomposite thin films. Mechanical properties were observed to fall with increasing copper content. The bacteria-killing efficiency of the films were also evaluated. The presence of $\mathrm{Cu}$ in the films led to the significant improvement of the anti-bacterial efficiency so that $100 \%$ of the bacteria killed after $80 \mathrm{~min}$ exposure time for the medium to high Cu contents. 


\section{ACKNOWLEDGEMENTS}

\section{This research has been supported by project FV30262, which is funded through the TRIO program of the Ministry of Industry and Trade, and project LM2018097 funded by the Ministry of Education, Youth and Sports of the Czech Republic.}

\section{REFERENCES}

[1] CRAWFORD, R.J., WEBB, H.K., TRUONG, V.K., HASAN, J., IVANOVA, E.P. Surface topographical factors influencing bacterial attachment. Adv. Colloid Interface Sci. 2012, vol. 179-182, pp. 142-149.

[2] SHARIFAHMADIAN, O., SALIMIJAZI, H.R., FATHI, M.H., MOSTAGHIMI, J., PERSHIN, L. Relationship between surface properties and antibacterial behavior of wire arc spray copper coatings. Surf. Coatings Technol. 2013, vol. 233, pp. 74-79.

[3] WANG, J., ZHAO, B., LI, G., YANG, K., et al. Study of TiCu/TiCuN multilayer films with antibacterial activity. Mater. Technol. 2020, vol. 35, pp. 475-482.

[4] LUO, J., HEIN, C., MÜCKLICH, F., SOLIOZ, M. Killing of bacteria by copper, cadmium, and silver surfaces reveals relevant physicochemical parameters. Biointerphases. 2017, vol. 12, pp. 020301.

[5] VINCENT, M., DUVAL, R.E., HARTEMANN, P., ENGELS-DEUTSCH, M. Contact killing and antimicrobial properties of copper. J. Appl. Microbiol. 2018, vol. 124, pp. 1032-1046.

[6] SHIMAZAKI, T., MIYAMOTO, H., ANDO, Y., NODA, I., et al. In vivo antibacterial and silver-releasing properties of novel thermal sprayed silver-containing hydroxyapatite coating. J. Biomed. Mater. Res. - Part B Appl. Biomater. 2010, vol. 92, pp. 386-389.

[7] JU, H., YU, D., YU, L., DING, N., et al. The influence of Ag contents on the microstructure, mechanical and tribological properties of ZrN-Ag films. Vacuum. 2018, vol. 148, pp. 54-61.

[8] FIELDING, G.A., ROY, M., BANDYOPADHYAY, A., BOSE, S. Antibacterial and biological characteristics of silver containing and strontium doped plasma sprayed hydroxyapatite coatings. Acta Biomater. 2012, vol. 8, pp. 31443152.

[9] CHEN, W., LIU, Y., COURTNEY, H.S., BETTENGA, M., et al. In vitro anti-bacterial and biological properties of magnetron co-sputtered silver-containing hydroxyapatite coating. Biomaterials. 2006, vol. 27, pp. 5512-5517.

[10] KELLY, P.J., LI, H., WHITEHEAD, K.A., VERRAN, J., et al. A study of the antimicrobial and tribological properties of TiN/Ag nanocomposite coatings. Surf. Coatings Technol. 2009, vol. 204, pp. 1137-1140.

[11] MUSIL, J., ZÍTEK, M., FAJFRLÍK, K., ČERSTVÝ, R. Flexible antibacterial Zr-Cu-N thin films resistant to cracking. J. Vac. Sci. Technol. A Vacuum, Surfaces, Film. 2016, vol. 34, pp. 021508.

[12] ZHANG, S., SUN, D., FU, Y., DU, H. Recent advances of superhard nanocomposite coatings: A review. Surf. Coatings Technol. 2003, vol. 167, pp. 113-119.

[13] MUSIL, J., ZEMAN, P., HRUBÝ, H., MAYRHOFER, P.H. ZrN/Cu nanocomposite film - A novel superhard material. Surf. Coatings Technol. 1999, vol. 120-121, pp. 179-183.

[14] PATSALAS, P., ABADIAS, G., MATENOGLOU, G.M., KOUTSOKERAS, L.E., LEKKA, C.E. Electronic and crystal structure and bonding in Ti-based ternary solid solution nitrides and Ti-Cu-N nanocomposite films. Surf. Coatings Technol. 2010, vol. 205, pp. 1324-1330.

[15] PENG, C., ZHAO, Y., JIN, S., WANG, J., et al. Antibacterial TiCu/TiCuN Multilayer Films with Good Corrosion Resistance Deposited by Axial Magnetic Field-Enhanced Arc lon Plating. ACS Appl. Mater. Interfaces. 2019, vol. 11, pp. 125-136. 